\title{
J. William Fulbright, the Contested Legacies of the American Revolution, and the War in Vietnam
}

\author{
Candace Sobers
}

In 1968, veteran Chair of the Senate Committee on Foreign Relations J. William Fulbright summoned a series of experts to a hearing on the Vietnam War and American foreign policy. The assembled academics were not asked to examine the minutiae of U.S. strategy and tactics in Vietnam, but to grapple with a more fundamental issue-what was the nature of revolution? The participants' testimonies interrogated the nation's revolutionary past to understand and inform their perspectives on Vietnam, the limits of U.S. power, and the contested legacies of the American Revolution. The hearings illuminated the intellectual history of an underexplored theme in U.S. foreign relations history - a marked ambivalence toward other people's revolutions, especially in the twentieth century, and the consequences of this contradictory posture for the United States's selfimage and foreign policy.

For if we did not precisely invent any of the instruments which these new nations are now using, we did illustrate their potentialities more fully and, I think, on the whole, more happily and more successfully than any other nation. The United States was the first nation to be founded squarely on the right of revolution-that is, the right to "alter or abolish government and institute new government." ... What was true in 1787 is, I think, true in 1967.

-Henry Steele Commager, $1967^{1}$

In the seventeenth century America escaped from the world, in the twentieth century it was forced to return to it.

Louis Hartz, July $1963^{2}$

The tumult of 1968 shook the globe. The Vietnam War had become one of the most divisive conflicts in United States history, and the sharp increase in American military involvement in Southeast Asia prompted protests and a critical re-examination of racism, militarism, and capitalism at home and overseas. Little wonder, then, that in the winter of 1968, the same moment as the Tet Offensive and CBS news anchor Walter Cronkite's famous criticism of the conduct of the war, veteran Chair of the Senate Committee on Foreign Relations (SCFR) J. William Fulbright summoned experts to testify at a series of public hearings on the Vietnam War and American foreign policy. These assembled academics were charged not with examining the minutiae of U.S. strategy and tactics in Vietnam, but with addressing a more fundamental

\footnotetext{
The author would like to thank Andrew M. Johnston, the editors of Modern American History, and five anonymous reviewers for their helpful comments.

${ }^{1}$ U.S. Congress, Senate, Committee on Foreign Relations, "Statement of Professor Henry Steele Commager, Professor of History, Columbia University," Changing American Attitudes Towards Foreign Policy, 90 Cong., 1 st sess., Feb. 20, 1967, 11 [hereafter SCFR].

${ }^{2}$ Louis Hartz, "American Historiography and Comparative Analysis: Further Reflections," Comparative Studies in Society and History 5, no. 4 (July 1963): 365-77, here 365.

(c) The Author(s), 2020. Published by Cambridge University Press
} 
issue: what was "the nature of revolution"?" The conveners intended "The Nature of Revolution" Hearings to consider whether Vietnam was a revolutionary situation. Yet a close reading of the hearings also revealed a far more interesting preoccupation: did a shared faith in the nobility of the United States's own revolutionary heritage help or hinder the nation's political decision makers in understanding the revolutionary aspirations of others?

In seeking to understand and inform their perspectives on Vietnam and the limits of U.S. power, the SCFR uncovered the contested legacies of the American Revolution. The proceedings revealed a significant contradiction: while Americans exalted in their own revolutionary heritage and sincerely believed the republic an example to the world, they simultaneously held that the American revolutionary experience was not replicable due to the unique circumstances of the late 1700s and the exceptional skills of the founding generation. Hearings participants anticipated that the U.S. experience and understanding of its own revolutionary past should enable a policy better able to handle the revolutionary impulses of others, and yet the opposite proved more often the case.

Responding in part to a challenge to seek new directions in the study of the Revolutionary Era and Early Republic, particularly its "contemporary invocations," this article presents one look at an underexplored theme in the history of U.S. foreign relations: a marked ambivalence toward twentieth-century sociopolitical revolutions, and the consequences of this contradictory posture for the nation's self-image and foreign policy. ${ }^{4}$ Indeed, the Nature of Revolution testimonies elicited elite perspectives on the American Revolution and its relationship with late 1960s U.S. foreign policy-perspectives best characterized as neither pro- nor counterrevolutionary, but of revolutionary ambivalence. While Fulbright posed the question of the nature of revolution, two prominent Harvard professors, historian Crane Brinton and political scientist Louis Hartz, answered it. Though respected in their fields, neither was a specialist on Vietnam, Southeast Asia, or even U.S. foreign relations. While other testimonies focused on Vietnamese nationalism, Brinton and Hartz expressed significant anxiety about the legitimacy of other people's revolutions and the capacities of non-Americans for true revolutionary change. These issues had a long history in the United States, of course, from the JeffersonAdams debates over the French Revolution through the Eisenhower administration's preoccupations with Fidel Castro. ${ }^{5}$ A close reading of these hearings illuminates this revolutionary ambivalence and informs models for how to understand the Vietnam War.

The earliest histories of the American Revolution, such as those written by David Ramsay in 1789 and Mercy Otis Warren in 1805, described it as a glorious cause for liberty and against

\footnotetext{
${ }^{3}$ U.S. Congress, Senate, Committee on Foreign Relations, "Statement of Dr. Louis Hartz, Professor of Government, Harvard University," in The Nature of Revolution: Hearings before the Committee on Foreign Relations, United States Senate, 90 Cong., 2nd sess., Feb. 26, 1968, 110 .

${ }^{4}$ Andrew M. Schocket, “The American Revolution: New Directions for a New Century," Reviews in American History 38, no. 3 (Sept. 2010): 576-86, here 586. See also Andrew M. Schocket, Fighting over the Founders: How We Remember the American Revolution (New York, 2017). On the transnational impacts of the American Revolution, see David Armitage, who lists over fifty significant global invocations of the Declaration of Independence in his 2008 study, The Declaration of Independence: A Global History (Boston, 2008). See also David Armitage, “The International Turn in Intellectual History," in Rethinking Modern European Intellectual History, eds. Darrin M. McMahon and Samuel Moyn (New York, 2013). On the current historiography of Revolutionary and Early Republic Studies, in a recent state-of-the-field review, David Waldstreicher added the "imperial school" to the traditional Whig/Progressive divide. David Waldstreicher, "The Revolutions of Revolution Historiography: Cold War Contradance, Neo-Imperial Waltz, or Jazz Standard?" Reviews in American History 42, no. 1 (Mar. 2014): 23-35, here 24. On the importance of the Jeffersonian "Empire of Liberty" and the "right" of Americans to intervene in tumultuous places to spread the blessings of liberty (and capital), see Odd Arne Westad, The Global Cold War: Third World Interventions and the Making of Our Time (Cambridge, UK, 2005), especially chapter 1.

${ }^{5}$ See Michael H. Hunt, Ideology and U.S. Foreign Policy (New Haven, CT, 1987). Indeed, Hunt (17-8) counts attitudes toward revolution, or "the limits of acceptable political and social change overseas," as one of the core ideas of U.S. foreign policy, along with the promotion of liberty and racial hierarchies.
} 
British perfidy, helping to create a now-familiar noble narrative. As the nation expanded, however, the quest for a nationalist creation story and a usable past intensified. ${ }^{6}$ As Joyce Appleby has noted, the generation born between Independence and 1800 "some enthusiastically, others reluctantly-took on the self-conscious task of elaborating the meaning of the American Revolution."7 For the next generation of historians, the Revolution acquired a religious dimension, becoming the end point of a providential plan to bring light to the New World. This Whig interpretation remained in vogue until the turn of the twentieth century (indeed, echoes of this interpretation are still found in populist accounts today). ${ }^{8}$ From military generals to political elites to yeoman farmers, the colonists were depicted as united in their opposition to British colonial "slavery," in their revulsion toward tyranny, and in their intrinsic understanding of the historical significance of the nation that emerged. ${ }^{9}$

Not until the Progressive Era was the Whig interpretation seriously challenged. As urbanization, industrialization, immigration, and World War I transformed the United States, Progressive historians looked back and spied similar class and ethnic conflicts in the Revolutionary Era. Scholars such as Charles Beard, Arthur M. Schlesinger, and J. Franklin Jameson explored linkages among geography, demographics, and economics, and analyzed the tensions between "sections" and special interests in the creation of the nation. ${ }^{10}$ Progressive historians also questioned the supposed radicalism of the founding era, arguing that a domestic elite had replaced their foreign precursors without dramatically changing an American society riddled with economic tensions. ${ }^{11}$

With the end of World War II emphasis returned to points of commonality among Americans. ${ }^{12}$ This so-called Consensus School inflected many aspects of intellectual life, including politics, government, jurisprudence, and the social sciences. When the consensus historians of the 1950s and early 1960s turned their analytical lenses to the American Revolution, they emphasized the roles of sober, propertied men, entirely rational in their fight for home rule. Mindful of the all-consuming ideological and political battle with the Soviet Union, early Cold War historians of the Revolution emphasized the Founders' adherence to the rule of law, the slow yet steady march of democracy, the definitive character of American liberalism, and the lack of truly divisive issues in American life. ${ }^{13}$ But events in the late 1960 s-among them rising revolutionary rhetoric and the proliferation of national liberation movements and potentially revolutionary situations across the globe-challenged these assumptions and

\footnotetext{
${ }^{6}$ David Ramsay, The History of the American Revolution, Vols. 1 and 2 (Philadelphia, 1789); and Mercy Otis Warren, History of the Rise, Progress, and Termination of the American Revolution: Interspersed with Biographical, Political, and Moral Observations (Boston, 1805). For a current take on the Loyalist counternarrative, see Maya Jasanoff, Liberty's Exiles: American Loyalists in the Revolutionary World (New York, 2012). On David Ramsay's impact on the historiography of the American Revolution, see Peter C. Messer, "From a Revolutionary History to a History of Revolution: David Ramsay and the American Revolution," Journal of the Early Republic 22, no. 2 (Summer 2002): 205-33.

${ }^{7}$ Joyce Appleby, Inheriting the Revolution: The First Generation of Americans (Cambridge, MA, 2000 ), 5.

${ }^{8}$ George Bancroft, History of the United States, from the Discovery of the American Continent, vols. 1-10, 1856 (Boston, 1844-1875). This Whiggish interpretation had little place for those who were not considered part of the body politic: most women, Native Americans, enslaved peoples, free Blacks, and Loyalists.

${ }^{9}$ Peter A. Dorsey, Common Bondage: Slavery as Metaphor in Revolutionary America (Knoxville, TN, 2009).

${ }^{10}$ A useful introduction to Progressive historiography is Ernst A. Breisach, American Progressive History: An Experiment in Modernization (Chicago, 1993).

${ }^{11}$ See Charles Beard, An Economic Interpretation of the Constitution of the United States (New York, 1913); Arthur M. Schlesinger, The Colonial Merchants and the American Revolution (New York, 1918); and J. Franklin Jameson, The American Revolution Considered as a Social Movement (Princeton, NJ, 1926).

${ }^{12} \mathrm{~A}$ moment presaged by the development of what became American Studies, circa 1940. I thank Andrew M. Johnston for this point.

${ }^{13}$ Hunt, Ideology and U.S. Foreign Policy, 17. Classic examples include Daniel J. Boorstin, The Genius of American Politics (Chicago, 1953) and Richard Hofstadter, The United States: The History of a Republic (Bergen, NJ, 1957), though Hofstadter rejected the label consensus historian.
} 
raised new questions about decolonization, radical change, and the role the United States should play as a global superpower. ${ }^{14}$ The fallout from the Vietnam War lent further urgency to the question.

More than four decades after the fall of Saigon, the war continues to fascinate and divide Americans (witness the popular and academic reactions to Ken Burns and Lynn Novick's 2017 PBS series The Vietnam War). ${ }^{15}$ Changing sociopolitical experiences, access to fresh sources, and new academic approaches have meanwhile inspired a new generation of Vietnam War historiography. ${ }^{16}$ Yet much of the writing on Vietnam remains shaped by two narratives: a mainstream academic "orthodox" perspective, which holds that the war was largely ill-advised and a lost cause, and a "revisionist" view, typically associated with military perspectives, in which the war was necessary and winnable but for the loss of support at home. ${ }^{17}$

Turning to a close analysis of the impacts of the discursive and affective legacies of the American Revolution on later U.S. foreign relations, particularly in the twentieth century, offers a new narrative framework and a new set of questions to ask about the Vietnam War, questions underexplored by historians but clearly on the minds of elite thinkers at the time of the SCFR hearings. First, was Vietnam a true nationalist revolution, rather than a site of foreign communist agitation? Second, how was the support of the right to nationalist revolt to be balanced with fears of communist infiltration and the disruption of the global order? Third, did the United States's own revolutionary heritage provide special insights into the roots and validity of sociopolitical upheavals in other states? And finally, did the legacy of the American Revolution imply a responsibility to support other nationalist revolutions? The issue was therefore not only the nature and perceived legitimacy of other people's revolutions, but how Americans felt about revolutions as a whole, including their own. ${ }^{18}$ The answers brought to light a profound revolutionary ambivalence that helps explain the sharp moral contradiction of a nation that oscillated between expounding the virtues of liberty and self-determination on the one hand and impeding movements for national liberation in the name of order and anti-communism on the other. The persistence of revolution as a category of contentious politics, the Cold War-decolonization nexus,

\footnotetext{
${ }^{14}$ Examples could be found in Asia (National Liberation Front/Việt Cộng in South Vietnam and Cambodia, Pathet Lao in Laos), the Middle East (Palestine Liberation Organization), Africa (Front de libération nationale in Algeria, National Liberation Front of Angola, South West Africa People's Organisation), Latin America and the Caribbean (Frente Sandinista de Liberación Nacional in Nicaragua, Revolutionary Armed Forces of Colombia), North America (Front de libération du Québec), and Europe (Euskadi Ta Askatasuna [ETA] in Spain and France). By the 1970s, a series of domestic "revolutionary fronts" also emerged in the West, such as the Rote Armee Fraktion in West Germany, and the Black Liberation Army and the Weathermen in the United States, who explicitly fought to "bring the war home."

${ }^{15}$ The ten-part series was the subject of a panel at the 132nd annual meeting of the American Historical Association in January 2018, "A Fateful Misunderstanding: A Discussion of the Film Documentary The Vietnam War by Ken Burns and Lynn Novick," as well as substantial coverage in The Washington Post and the New York Times, among others.

${ }^{16}$ Among the more innovative recent contributions to the history of the Vietnam War are those that use non-English source material, explore the conflict's impact on transnational actors and revolutionary movements elsewhere, or otherwise embed the war in broader international contexts. See, for example, Sophie Quinn-Judge, Ho Chi Minh: The Missing Years (Berkeley, CA, 2002); Mark Philip Bradley and Marilyn B. Young, eds., Making Sense of the Vietnam Wars: Local, National, and Transnational Perspectives (New York, 2008); Pierre Asselin, Hanoi's Road to the Vietnam War, 1954-1965 (Berkeley, CA, 2013); Chen Jian, Mao's China and the Cold War (Chapel Hill, NC, 2001); Westad, The Global Cold War; Mark Atwood Lawrence, The Vietnam War: A Concise International History (New York, 2010); Judy Tzu-Chun Wu, Radicals on the Road: Internationalism, Orientalism, and Feminism During the Vietnam Era (Ithaca, NY, 2013); Heather Marie Stur, Beyond Combat: Women and Gender in the Vietnam War Era (Cambridge, MA, 2011); and Paul Thomas Chamberlin, The Global Offensive: The United States, the Palestine Liberation Army and the Making of the Post-Cold War Order (New York, 2012).

${ }^{17}$ I thank an anonymous reviewer for this point.

${ }^{18}$ John Adams and Thomas Jefferson's debates over the French Revolution were legendary, though Michael Hunt argues that their views converged as they aged. Hunt, Ideology and U.S. Foreign Policy, 94-100.
} 
and the nation's revolutionary ambivalence meant that for U.S. foreign policy elites, revolutions were, in the words of Louis Hartz, a problem "entangled with our destiny."19

As President Lyndon Johnson escalated and Americanized the war in Vietnam, members of Congress took note. Whether Johnson's freedom to maneuver was circumscribed by Kennedy's legacy and the hawkish wing of the Democratic Congress or by his own hubris, officials explained the expanding engagement in Vietnam in internationalist terms. The credibility of Johnson's presidency and of the Democratic Party, as well as the U.S.'s ability to act as guarantor of the international order, were at stake and the pressure was felt acutely throughout the administration. ${ }^{20}$ But as the fighting in Vietnam became costlier and more visible, it prompted a sustained examination of U.S. policy. As Chair of the SCFR, Fulbright considered it his duty to keep a sharp eye on the nation's foreign interventions.

Fulbright remains an enigmatic character in twentieth century U.S. political history. ${ }^{21}$ On questions of race, Fulbright was a quintessential Southern Democrat; the junior senator from Arkansas signed the 1956 "Southern Manifesto" against mandatory racial integration in the wake of Brown v. Board of Education (1954), filibustered the Civil Rights Acts of 1957 and 1964, and voted against the 1965 Voting Rights Act. Yet Fulbright proved iconoclastic on questions of foreign policy. He was a Wilsonian with similar racial prejudices and a comparable aversion to European imperialism, a perspective often shared by Southerners. ${ }^{22} \mathrm{He}$ was a keen supporter of international law and the United Nations. At a time when most Southern Democrats were zealous anti-communists, Fulbright clashed openly with both Senate McCarthyites and Secretary of State John Foster Dulles. In 1956, Harper's called the junior senator the "Arkansas Paradox." ${ }^{23}$ A decade later journalist Marquis Childs described Fulbright as a "bemused college professor," concerned as a "humanitarian and a scholar" with the Johnson administration's "willingness to sacrifice human lives" over Vietnam. ${ }^{24}$

Until the 1960s Fulbright was most famous for his eponymous educational exchange program and his oft-repeated belief in the redemptive powers of education. ${ }^{25} \mathrm{He}$ had established

\footnotetext{
${ }^{19}$ SCFR, "Statement of Dr. Louis Hartz, Professor of Government, Harvard University," 110. For notes on the "persistence" of revolution, see Fred Halliday, "Revolutionary Internationalism and Its Perils," in Revolution in the Making of the Modern World: Social Identities, Globalization, and Modernity, eds. John Foran, David Lane, and Andreja Zivkovic (London, UK, 2008), 65-80; Fred Halliday, Revolution and World Politics: The Rise and Fall of the Sixth Great Power (Durham, NC, 1999).

${ }^{20}$ Fredrik Logevall, Choosing War: The Lost Change for Pease and the Escalation of War in Vietnam (Berkeley, CA, 2001), xiv-xvi.

${ }^{21}$ Fulbright's preeminent biographer is Randall Bennett Woods, who has written J. William Fulbright, Vietnam, and the Search for a Cold War Foreign Policy (Cambridge, MA, 1998) and the definitive Fulbright: A Biography (Cambridge, MA, 1995). See also Woods, Vietnam and the American Political Tradition: The Politics of Dissent (Cambridge, MA, 2003). Other assessments focusing on Fulbright's political dissidence include William C. Berman, William Fulbright and the Vietnam War: The Dissent of a Political Realist (Kent, OH, 1988); Eugene Brown, J. William Fulbright: Advice and Dissent (Iowa City, IA, 1985); and Haynes Johnson and Bernard Gwertzman, Fulbright: The Dissenter (New York, 1968). Most recently, see Douglas A. LeVien III, "America's Prescient Dissenters: Senator J. William Fulbright and Dr. Andrew J. Bacevich's Principled Dissent of US Policy in Vietnam and Iraq and Their Enduring Perspectives," Journal of Military Ethics 16, nos. 3-4 (2017): 173-90. Brown (1985) challenges the "dissenter" narrative. Finally, there is the entertaining but questionable account in journalist Tristram Coffin's Senator Fulbright: Portrait of a Public Philosopher (London, 1966).

${ }^{22}$ Randall Bennett Woods, “Dixie’s Dove: J. William Fulbright, the Vietnam War, and the American South,” The Journal of Southern History 60, no. 3 (Aug. 1994): 533-52, here 549-50.

${ }^{23}$ As evidence of Fulbright's peculiarity, an unnamed "party leader" said of the junior senator: "He's brilliant and capable, but he'd rather make commencement addresses to young eggheads than a good, rousing Jackson-Jefferson day speech." Charles B. Seib and Alan L. Otten, "Fulbright: Arkansas Paradox," Harper's Magazine, June 1, $1956,60$.

${ }^{24}$ Marquis Childs, "Fulbright's Role as Sober Critic," The Washington Post, Monday, Apr. 4, 1966, A16.

${ }^{25}$ Brown, J. William Fulbright, 49.
} 
himself as a critic and intellectual who challenged what he considered to be the false assumptions distorting American foreign policy. On March 25, 1964, Fulbright addressed the Senate with a speech entitled "Old Myths and New Realities." Due to human fragilities, there was always some "divergence" between the world as it was and the world "as men perceive it." This was especially true in foreign policy, and particularly problematic for Americans "predisposed to regard any conflict as a clash between good and evil rather than as simply a clash between conflicting interests." ${ }^{26}$ The central "old myth" was that of a centralized communist conspiracy, with different actors and agents "all equally resolute and implacable in their determination to destroy the free world." ${ }^{27}$ Two years later, in his most well-known address, Fulbright lectured a Johns Hopkins audience on "The Arrogance of Power," arguing that the U.S. was "in danger of losing its perspective on what exactly [was] within the realm of its power and what [was] beyond it." ${ }^{28}$ Fulbright insisted that the United States was powerful enough to have the "courage to be wrong" about its foreign relations. ${ }^{29}$ When Fulbright finally broke with the administration over Vietnam, it was dramatic but not entirely unprecedented.

Fulbright the politician may have been an odd fit with his Senate colleagues and seemed to have a unique ability to alienate those closest to power, but Fulbright the political intellectual was a well-respected public figure in liberal internationalist circles. ${ }^{30}$ To quote Walter Lippmann, "Fulbright is not listened to on the floor of Congress until he has been heard around the world." ${ }^{31}$ Hosting hearings was therefore entirely in keeping with Fulbright's conception of the role of a senator-as-intellectual and his desire to influence politics by shaping the conversation, rather than through legislative change or having the ear of decision makers. ${ }^{32}$

After 1965, as U.S. military commitments in Vietnam escalated sharply, Fulbright used the chair's prerogative to convene a series of ongoing conversations about the use and misuse of American power in general, and about Johnson's Southeast Asia policies in particular. Fulbright turned to a rotating series of experts from government, the military, and academia. The hearings probed the "larger geopolitical and ideological rationale for and meaning of US involvement" and provided a window into a series of issues raised by the war, including the validity of the domino theory, whether or not American credibility hinged on defeating North Vietnam, why the nation's superior military technology was not producing the expected results, and the ultimate position of the United States in the story-defender of liberty or global bully? ${ }^{33}$ Not just the concerns of the emergent antiwar left, these questions also troubled Congressional elites and high-ranking political actors.

\footnotetext{
${ }^{26}$ J. William Fulbright, "Old Myths and New Realities," Congressional Record: Proceedings and Debates of the 88th Congress, 2nd sess., 110, no. 56, Mar. 25, 1964, University of Arkansas Libraries, Fayetteville, AR, https:// digitalcollections.uark.edu/digital/collection/Fulbright/id/307.

${ }^{27}$ Brown, J. William Fulbright, 57-9. In 1965, Fulbright also publicly challenged the Johnson administration on its military intervention in the Dominican Republic.

${ }^{28}$ Fulbright later published the text in its entirety in 1966. J. William Fulbright, "The Arrogance of Power," delivered at the School of Advanced International Studies, Johns Hopkins University, Baltimore, MD, May 5, 1966, J. William Fulbright Papers (MS F956 144, Series 72, Box 26, File 9), University of Arkansas Libraries, Fayetteville, AR, http://scipio.uark.edu/cdm/ref/collection/Fulbright/id/589.

${ }^{29}$ Joseph A. Fry, Debating Vietnam: Fulbright, Stennis, and Their Senate Hearings (Lanham, MD, 2006$), 9$.

${ }^{30}$ And correspondingly loathed in conservative circles. Magazines such as Human Events devoted copious space to questioning Fulbright's sanity and patriotism and calling for his resignation.

${ }^{31}$ Brown, J. William Fulbright, 5.

${ }^{32}$ Ibid.

${ }^{33}$ Fry, viii-ix. Senator John C. Stennis (D-MS) was chair of the Democratic Preparedness Investigating Committee of the Senate Armed Services Committee and an ardent supporter of the war, notable for suggesting the use of tactical nuclear weapons in Vietnam. Stennis's own hearings began in August 1967 and were aggressively pro-military engagement in Vietnam. For a current discussion of Stennis, see Robert K. Brigham, "Lyndon Johnson vs. the Hawks," New York Times, Aug. 29, 2017, https://www.nytimes.com/2017/08/29/opinion/lyndon-johnsonvietnam-senate.html.
} 
Lofty goals notwithstanding, the hearings were often a mixed bag. Some were highly orchestrated political theater, interrogating high-ranking officials such as Secretary of State Dean Rusk and Secretary of Defense Robert McNamara, with Fulbright conspicuously wearing dark glasses to shield himself from the television lights. ${ }^{34}$ Others had fewer than ten people in the room and passed with little fanfare. Some explicitly focused on the prosecution of the war, such as John Kerry's April 1971 "Winter Soldier" testimony on behalf of Vietnam Veterans against the War. ${ }^{35}$ Still others explicitly handled the broadest questions about U.S. history, the nation's values, and its changing role in a decolonizing world.

Throughout the twentieth century, movements for national liberation had increased, and sociopolitical revolution was once again a subject of popular and academic attention. ${ }^{36}$ The 1960s and 1970s arguably represented the height of an increasingly global pan-liberationist cosmology, where the popular appeal of revolution was present everywhere from Paris to Mexico City and from Soweto to Harvard Yard. The rise of radical ideologies and practices also inspired American revolutionaries to pursue radical social transformations at home and abroad, and to stand in solidarity with revolutions in the decolonizing world.

Fulbright's hearings showcased how elite Americans tried to understand revolutionary upheaval with the assistance of academic specialists-a penchant that reflected the growing commitment to professionalization and positivist thinking that characterized post-1945 social science. ${ }^{37}$ In 1967, for example, Fulbright invited prominent historian Henry Steele Commager to speak before the committee on the subject of "Changing American Attitudes Toward Foreign Policy." Known for his critical liberal analyses, Commager was introduced by Fulbright as "one of our Nation's most celebrated scholars in the field of American history." Commager was asked to comment on the history of U.S. foreign relations and on the nation's handling of its new global standing.

Commager forcefully declared that Americans had long recognized the necessity of limits to political power. Indeed, "our political philosophy ... is a monument to the belief that power is

\footnotetext{
${ }^{34}$ According to Julian Zelizer, "Johnson came to hate Fulbright, whom he privately mocked as 'Senator Halfbright.' But the Hearings stung the president." Julian Zelizer, "How Congress Got Us Out of Vietnam," The American Prospect, Feb. 19, 2007, https://prospect.org/features/congress-got-us-vietnam/.

${ }^{35}$ The University of Richmond hosts a useful edited version of Kerry's testimony, with notes provided by Ernest Bolt. "Vietnam War Veteran John Kerry's Testimony before the Senate Foreign Relations Committee, April 22, 1971," University of Richmond, https://www.lschs.org/cfhttp.cfm?script=extensions/includes/resource/resourcecontent. cfm\&pageid=608\&rid=271.

${ }^{36}$ David Armitage, "Every Great Revolution Is a Civil War," in Scripting Revolution, eds. Keith Michael Baker and Dan Edelstein (Stanford, CA, 2015), 57-70.

${ }^{37}$ So intense was the drive to understand and control revolutionary movements that joint ventures like the Special Operations Research Office (SORO), based at American University in Washington, DC, linked universities, government, and the Pentagon in the pursuit of counterinsurgency strategies to predict and manage revolutionary change and political instability in the Third World. Think tanks, intelligence, and defense agencies adopted psychological warfare techniques to destabilize rebels and win the "hearts and minds" of Third World peoples, albeit with limited success. Numerous studies expose the links between Cold War social science, modernization theory, and military objectives, including Joy Rohde, Armed with Expertise: The Militarization of American Social Research During the Cold War (Ithaca, NY, 2013), especially chapter 4; and Mark Solovey, Shaky Foundations: The Politics-Patronage-Social Science Nexus in Cold War America (New Brunswick, NJ, 2013). Both Rohde and Solovey discuss the rise of postwar scientism and the evolving relationship between academia, government, and the military. In particular, both works highlight Project Camelot, a 1964 American University-Army initiative that employed top social scientists to develop a systems theory approach to predicting and forestalling revolution and political instability in Latin America. See also Ellen Herman, The Romance of American Psychology: Political Culture in the Age of Experts (Berkeley, CA, 1995); Mark Solovey, "Project Camelot and the 1960s Epistemological Revolution: Rethinking the Politics-Patronage-Social Science Nexus," Social Studies of Science 31, no. 2 (2001): 171-206; and Mark Solovey and Hamilton Cravens, eds., Cold War Social Science: Knowledge Production, Liberal Democracy, and Human Nature (New York, 2012). Cold War exigencies also led to the rise of think tanks such as the Rand Corporation and the endowment and transformation of the university sector. See Rebecca S. Lowen, Creating the Cold War University: The Transformation of Stanford (Berkeley, CA 1997).
} 
limited, and that power should be limited." And as power was constrained domestically through the elaborate system of checks and balances, so should it also be limited in foreign relations. In Commager's telling, the main traditions in American foreign relations history all reflected this respect for limits. The American Revolution was a response to the Declaratory Act of 1766, which had argued for the Crown's right to "bind the Colonies and people of America in all cases whatsoever." George Washington's Neutrality Proclamation in 1793 limited American engagement in European affairs, and both the Monroe Doctrine and the Open Door could be interpreted as policies in which the United States encouraged European restraint, but also set global limits for itself. Commager also articulated the "accidental" explanation for the nation's overseas domain: Spanish territories were acquired in a "fit of absentmindedness"; Cuba was "very sensibly" returned to the Cubans; and Americans were "eager to get out" of the Philippines.

The United States's penchant for international restraint, then, had allowed it to "go before the world with clean hands, as it were: we do not have "colonies." 38 But Commager believed that the two world wars "inextricably" bound the United States to the affairs of Europe and the world, and had stretched traditions too far. Americans successfully helped Europe and Asia rebuild, but the policy of restraint was abandoned to the nation's detriment. Commager argued that it was now the United Nations's duty, not that of the United States, "to keep peace throughout the globe, to put down aggression wherever it starts up, to stop the advance of communism or other isms which we may not approve of."39

Commager's statement anticipated several core themes raised in the Nature of Revolution testimonies a year later. First was his argument that the careless deployment of American might around the globe represented a betrayal of American values. Second was Commager's insistence that participants take a wider historical perspective in their deliberations. The communist revolutions that so many policy makers interpreted as immediate threats to global stability were for others the natural culmination of centuries of oppression. As Commager reminded the assembled senators, "It was the West-not communist countries-that invented imperialism and invented colonialism." And finally, Commager suggested that perhaps the United States owed the world a debt of revolution. The American Revolution was the preeminent example of radical, liberatory political transformation. As such, the U.S. had to bear some responsibility for the seismic change in the international system denoted by "the revolt of Asia and Africa against the West.... and the emergence into modernity of perhaps two-thirds of the peoples of the globe." ${ }^{\prime 0}$ As the "first people to create a nation," Americans should be "infinitely sympathetic to the new nations of the world." Instead, Commager concluded, the United States too often found itself opposed to revolution, to the great disenchantment of emerging nations, weakening the nation's moral authority. ${ }^{41}$

In February and March 1968, the Foreign Relations Committee convened the Nature of Revolution hearings, and entertained the testimony of five academics from the fields of history, political science, and government. ${ }^{42}$ The academics had a difficult task. They were summoned before a bipartisan, high-level Senate committee of career politicians not to discuss Vietnam strategy or Vietnamese nationalism, but to consider the far more ambiguous topic of

\footnotetext{
${ }^{38}$ SCFR, "Statement of Professor Henry Steele Commager, Professor of History, Columbia University," 5.

${ }^{39}$ Ibid., 8.

${ }^{40}$ Ibid., 11.

${ }^{41}$ Ibid.

${ }^{42}$ In addition to Crane Brinton and Louis Hartz, testimonials came from Richard Solomon, assistant professor of political science at the University of Michigan, and James Thomson, Jr., assistant professor of history at Harvard. Both men were China experts and testified on the second day, February 21. Also testifying on March 7 was John T. McAlister of the Woodrow Wilson School at Princeton, a Vietnam specialist who had served two years as an advisor to the River Force of the Vietnamese Navy while an active Lieutenant in the U.S. Naval Reserve.
} 
revolution. ${ }^{43}$ While three of the academics were present for their area expertise, Crane Brinton and Louis Hartz, like Commager before them, were called for their knowledge of history and government.

On Monday, February 19, Fulbright called the meeting to order:

The Committee on Foreign Relations this morning is beginning a series of public Hearings on the nature of revolutions and the significance of revolutions abroad for American foreign policy. The broad purpose of these open discussions is, first, to develop information about the tendency of revolutions, regardless of their ideological origins, to pass through certain relatively distinct stages, and, second, to try to identify the implications of the process in the context of the current and future formulation of foreign policy by the United States. ${ }^{44}$

Brinton testified first. A specialist on revolutions and the history of France, known to combine sweeping historical analysis with observations of contemporary ethical and political issues, Brinton had offered a few general reflections on global affairs and U.S. policy in his publications. In 1947, in a collection of addresses delivered at Pomona College entitled From Many One: The Process of Political Integration, the Problem of World Government, he argued that the new challenges of the postwar era required the intervention of social scientists. Brinton quoted the chilling remark of an unnamed academic colleague: "We physical scientists have now succeeded in devising a way-several ways-to destroy the human race; you social scientists have got to find a way to keep the human race from using the opportunity we have given it." Brinton emphasized that historians had a necessary role in creating this new political age. Since all the "treaties, alliances, leagues, united nations [sic], and any other device for bringing sovereign states together" had not yet worked, it was up to historians to discern which aspects of political integration had worked in the past and could be adapted for a nuclear world. ${ }^{45}$

For Brinton, there existed two grand models of political integration: imperialism (integration by force) and federalism (integration by consent), and neither was suitable for the postwar world. Imperialism was obviously problematic, as it relied on artificial hierarchies and coercion. Moreover, imperialism's legitimacy as a form of political organization had been severely damaged by the Second World War and was further threatened by rising Asian nationalism. Democratic federalism, the model pioneered by the United States, though superior to imperialism, was a poor fit for mid-twentieth-century political integration. The sociopolitical experiment of American federalism, which absorbed a once adversarial multitude of distinct European peoples into a "melting pot of races," could not be replicated on the scale necessary for global peace. ${ }^{46}$ To attempt such would be logistically impractical, as there were simply too many people in the world, "some twenty-two thousand million of them," of differing political traditions and levels of development. As Brinton explained, even if one excluded the "black Africans and Polynesians, you can hardly rule out [the] Chinese, Japanese, and East Indians" from the new global political compact. ${ }^{47}$ There lay the dilemma. If integration by force was out of the question, so then was control by the traditional imperial powers, France

\footnotetext{
${ }^{43}$ Typically, mainstream American discourse on the Vietnam War did not invoke the idea of revolution, referring to the conflict alternatively as a civil war, a war of national liberation, or a communist insurgency. And yet in certain left-wing circles, "it was not unusual for Vietnam (1975)" to be included among the great Third World social revolutions, alongside China (1949), Cuba (1959), and Algeria (1962). Eric Selbin, Revolution, Rebellion, Resistance: The Power of Story (London, UK, 2010), 117.

${ }^{44}$ SCFR, "Statement of Dr. Crane Brinton, Professor of History, Harvard University," 1.

${ }^{45}$ Crane Brinton, From Many One: The Process of Political Integration, the Problem of World Government (Westport, CT, 1971), 3-5.

${ }^{46}$ Brinton, From Many One, 23.

${ }^{47}$ Ibid., 105.
} 
and Britain. The obvious alternative was U.S. global leadership, yet Americans were a distinct people who possessed neither the inclination nor "the stuff of imperialists." ${ }^{38}$ Brinton argued that a "pax Americana" was both inadvisable and impossible:

We Americans have many assets for the task, but I do not believe we could make a pax Americana for the globe. We have great energy, and we are today as ubiquitous in the furthest corners of the world as was once the Englishman. We have to the full the great Anglo-Saxon gift of identifying our desires with universal human obligations. We should never attempt, as Hitler did, to conquer cruelly for our own avowed good; when we conquer people, or indeed have any dealing with them, we do so for their good. ${ }^{49}$

There was an additional difficulty-nationalism. Here Brinton adopted the language of English writer Arthur Clutton-Brock, who in 1921 defined nationalism as "pooled selfesteem." Nationalism remained a constant, "not to be stamped out by conquest, nor even to be exorcised by professorial and editorial incantations." In a gibe at the Cold War realists already dominating political discourse (Hans Morgenthau's Scientific Man versus Power Politics was published in 1946, Politics Among Nations followed in 1948), Brinton pointed out that "oppressed nationalities like the Irish and the Poles" were remarkably persistent in their refusal to be subsumed by stronger powers. Much to the annoyance of those "afflicted" with realism, "the human sentiments that bind men into nationalities are deep, slow to change, and like many other human sentiments, are often strengthened by attempts to suppress them." 51 Thus, whatever form of political integration would save the world from further atomic terror would require "deliberate human volition" to eradicate "festering sores of unsatisfied nationalism, [and] irredenta, internal or external." 52

The threat of unfulfilled nationalist aspirations and the irreplaceability of the American historical experience were key themes in Brinton's postwar work, but his 1938 title, The Anatomy of Revolution, made Brinton's academic reputation and formed the basis of his prepared remarks before the SCFR three decades later. ${ }^{53}$ In his testimony Brinton reintroduced his famous medical metaphor, likening revolutions to a fever wherein discontent with the ancien régime festered until the elites defected and there developed widespread call for systemic change. Gradually, moderate reformers lost control to better organized radicals, who in turn lost control to the most violent extremists, precipitating social catastrophe (borrowing from the French Revolution, Brinton called this period a "reign of terror"). ${ }^{54}$ After a period of

\footnotetext{
${ }^{48}$ Brinton was unconvinced that the Soviet Union had designs on global domination, but more importantly, he believed it also lacked the technological capabilities to achieve it. Brinton, From Many One, 97.

${ }^{49}$ Lest cynicism be read into the above statement, Brinton was explicit that he was quite serious. Brinton, From Many One, 96.

${ }^{50}$ Brinton, From Many One, 75.

${ }^{51}$ Brinton felt that for realists the persistence of nationalisms was "rather annoying. They can hardly deny the fact of such persistence, but on their own principles they can hardly explain it." Brinton, From Many One, 73.

${ }^{52}$ Ibid., 73-5.

${ }^{53}$ Crane Brinton, The Anatomy of Revolution (New York, 1938). While Brinton employs the medical motif throughout the work, see especially 26-30. Though less famous than Hartz, Brinton himself has been the subject of some study. See John Layton Harvey, “History Written with a Little Spite': Palmer, Brinton, and an American Debate on the French Revolution," Historical Reflections/Réflexions Historiques 37, no. 3 (Winter 2011): 38-55. Matthew R. Beland, “Anatomy of a Classic: Crane Brinton's 'The Anatomy of Revolution"” (Ph.D. diss., Drew University, 2008) employs a book history approach to account for Anatomy's enduring popularity.

${ }^{54}$ Becoming a successful revolutionary leader, what Brinton called "entrepreneurship of revolution," required four skills: invention of ideas/theories, spreading ideas and getting them accepted ("in short, the task of the propagandist and advertiser"), creating personal loyalty and devotion, and last, targeting "the manipulator in the narrow sense, the man in the smoke-filled room, who deals not with the masses, but personally and directly with the few important men at the top." Lenin was his classic example. Crane Brinton, "The Manipulation of Economic Unrest," The Journal of Economic History 8 Suppl. (1948): 21-31, here 25-6.
} 
convalescence, society settled back down, forever altered, but often not nearly as radically as the revolutionaries had initially hoped. ${ }^{55}$ Anatomy of Revolution set the stage for decades of study on comparative revolutions. Brinton was not uncommon in his academic distaste for the French Revolution, but he was unique in that his ideas reached both academic and general audiences. $^{56}$

This broad pattern characterized all the great revolutions, except the American one, which Brinton described to the Foreign Relations Committee as a "successful nationalist revolution" to expel British rulers that Americans had come to view as foreigners in their midst. The American Revolution shared with other revolutions a transfer of allegiance from the legitimate authority in the imperial metropole to local elites and a compelling narrative of social change, but it avoided the violence that characterized France and Russia. Brinton noted that the "Declaration [of Independence] marked the victory of the radicals-I will not call them extremists-over the moderates. Our revolution can still arouse in us emotions not aroused by other revolutions." ${ }^{57}$ Perhaps mindful of the sensitivities of his audience, Brinton carefully noted that the American colonists had created a revolution for territorial expansion to support a growing nation and not to spread a "revolutionary faith." ${ }^{\text {" }} \mathrm{He}$ also admitted there was "a general overall feeling among good solid Americans-since our own revolution is so long past-to ennoble their own revolutionary past but to dislike current ones as not so noble. England is a very nice example of such a tendency. They have even tried to forget the fact that they once cut a king's head off. They don't like to be reminded."59

After Brinton's testimony Fulbright steered the discussion, asking questions about the success ratio of modern revolutions and segueing quickly into questions about the U.S.'s interventionist tendencies. Brinton claimed that in the Mexican Revolution (1910-1920) a stable, democratic polity developed because the Americans had not interfered. Fulbright pressed him: "Is it true that in most of our interventions we haven't been very successful in trying to bring about a revolution and the creation of a better society?" Brinton hedged, responding that the nation's interventions had mostly been in the Americas and did not necessarily "count," dismissing "the conventional opera bouffe South American revolution." In Brinton's estimation, "where we have attempted to intervene, notably at present in the Vietnam revolution which I regard as a very complicated one indeed, at the moment we seem not to have been successful." 60

At this point Al Gore, Sr. (D-TN) inquired about the role of "esprit gospel" and the "dedications of faith and ideology," which were so central to the spread of revolutionary movements. Gore was "rather proud of the American evangelical spirit" and the proverbial shot heard around the world at Lexington and Concord in April 1775. Linking revolutionary and religious fervor, Gore's comments pointed to a fundamental aspect of American political thought: the U.S. had the "most aggressive religious culture in modern days ... having spread its influences to the darkest most spots of every continent." ${ }^{61}$ In Gore's words, Americans "have the best and we insist that our sense of values [are] superior and, therefore, we want to make them available. We are a little impatient when people do not accept them." Yet even Gore admitted that current attempts to spread these values to Vietnam had run into a series of formidable philosophical

\footnotetext{
${ }^{55}$ Brinton, Anatomy of Revolution, 26-7, 186-97.

${ }^{56}$ Harvey, "'History Written with a Little Spite," 47.

${ }^{57}$ SCFR, "Statement of Dr. Crane Brinton, Professor of History, Harvard University," 7-8.

${ }^{58}$ Ibid., 15.

${ }^{59}$ Ibid., 30.

${ }^{60}$ Brinton attributed at least part of the successful outcome in Mexico in part to "the fact that Mr. Roosevelt did not imitate Mr. Wilson in sending troops in." SCFR, "Statement of Dr. Crane Brinton, Professor of History, Harvard University," 12. Here both Fulbright and Brinton appear to have forgotten or discounted the U.S. intervention in Veracruz in 1918. I thank an anonymous reviewer for this point.

${ }^{61}$ SCFR, "Statement of Dr. Crane Brinton, Professor of History, Harvard University," 15.
} 
and material obstacles. Americans were now "in confrontation with another aggressive culture that is inspired by a sort of materialistic fanaticism. I can't quite call it religion.” Perhaps Americans had erred in spreading the gospel of revolution around the globe, since modern revolutions were so expansionary and aggressive, and since modern revolutionaries seemed unappreciative of American solicitations. ${ }^{62}$

Brinton agreed that the "gospel" of a revolution was a critical factor. Earlier, he had inveighed against the prevailing trend toward scientism and quantification, which detracted from a true understanding of what motivated political action. Brinton emphasized the importance of ideology in the mobilization of revolutionary sentiments, since ideas distinguished "a revolutionary crisis from ordinary political, military, or economic crisis." ${ }^{63}$ Though Cold War Americans derided ideology as the preserve of communists and radicals, Brinton criticized "current American opinion which tends to minimize the importance of ideas as not being hard boiled, concrete, and realistic." ${ }^{64}$ For this reason the emerging "national liberation fronts, and so forth, and so on, mostly in Asia and Africa" were the classic revolutionary type, that is, "mixed socioeconomic and nationalist but with nationalism at its core." 65 The crux of the matter was whether self-determination and democracy were Western or Eastern principles. As Gore saw it, the U.S. attempted to "make available Western values to Southeast Asia, [...] attempting to measure our problem there by Western values." Gore had "serious doubts that Western values [were] an adequate index for policy." Brinton replied that self-determination- "those famous words" - were "good American words" for an American context, yet the desire to create affective groups above the level of kin or family was a natural desire that "went back to the tribal." The goal of an independent nation-state was simply the most recent iteration of this longstanding aspiration, one Americans were "running up against now" in the decolonizing world. ${ }^{66}$

George Aiken (R-VT) finally turned the discussion to Vietnam, asking if "what is going on in Vietnam today is a revolution, a bona fide revolution, or is it a widespread Communist conspiracy to take over the world? How would you treat those two influences?" ${ }^{\prime 67}$ Aiken was already infamous for allegedly stating in 1966 that the United States should declare victory in Vietnam and get out. ${ }^{68}$ Brinton responded that the idea of a global communist conspiracy for world domination did not "make much sense in view of the relations between Russia and China, to say nothing of some of the minor communist states and Yugoslavia and indeed North Korea as far as that goes." There was no doubt that Ho Chi Minh was a communist, but Ho was closer to a Tito, more concerned with building a nationalist program than executing orders from Moscow. ${ }^{69}$

Next, Aiken inquired about the wave of anticolonial resistance movements sweeping Africa, Asia, and Latin America, and the fear of revolutionary violence in places such as Congo, where "revolution has been going on all the time," or in other volatile places like Nigeria, Thailand, or Burma. ${ }^{70}$ Despite the common belief that poorer nations were most susceptible to both

\footnotetext{
${ }^{62}$ Ibid., 17.

${ }^{63}$ Ibid., 10.

${ }^{64}$ Ibid., 15.

${ }^{65}$ Ibid., 13.

${ }^{66}$ Ibid., 18-9.

${ }^{67}$ Ibid., 20.

${ }^{68}$ Though Aiken's actual comments were less inflammatory (he advocated a change in the U.S.'s stated goals and a corresponding new strategic redeployment), he had already made a reputation as a critical voice on Vietnam: "If we can get out of Vietnam with the respect of the world and still insure South Vietnam will be left for the South Vietnamese it will be a miracle." See Mark A. Stoler, "What Did He Really Say? The 'Aiken Formula' for Vietnam Revisited," Vermont History 46, no. 2 (Spring 1978): 100, 103. https://vermonthistory.org/journal/misc/ AikenVietnam.pdf.

${ }^{69}$ SCFR, "Statement of Dr. Crane Brinton, Professor of History, Harvard University," 20.

${ }^{70}$ Ibid., 23.
} 
communist influence and internal disorder, Brinton did not believe that poverty alone was a catalyst for revolution. Earlier in his testimony Brinton explicitly stated that revolutions did not occur among the "miserable and downtrodden and the desperate," but among "people who have enough to want more." ${ }^{71}$ And indeed, revolutions would proliferate now that a critical mass of once-colonized peoples had "enough to want more," and were willing to adopt Marxism to get it. The world was in another age of revolution: "One can break out most anywhere really and especially in the underdeveloped nations or whatever you call them. I think there is no question about it." If revolutions were now an unavoidable part of the contemporary geopolitical landscape, how should the U.S. respond? Brinton offered "no simple formula" other than prudence. The U.S. could not support or "bless" every case of revolutionary upheaval; there could be no endorsement of "what Castro did in Cuba," for example, but too much counterrevolutionary interference was also a flawed strategy. Returning to his medical metaphor, the United States should approach each case of upheaval like a wise physician attending to an illness, following the Hippocratic oath of "do no harm."72

Fulbright also wanted Brinton's expertise on the subject of whether communism led to excesses such as purges and show trials, and whether a period of political violence was characteristic of revolutions in general, or of the communist variant specifically? ${ }^{73}$ Brinton was unequivocal that violence was a part of all revolutionary processes. The United States had to manage the increasing complexity of the international system and the difficulty of maintaining a balance of forces amenable to American interests. Vietnam and the rise of sociopolitical revolutions in other parts of the world only compounded this issue.

Clifford P. Case (R-NJ) wondered if Brinton "would just sort of speculate about the relationship, if any, between local revolution and the larger question of the balance of power":

We vacillate back and forth between thinking how horrible it is that we, a great power, are destroying a little country at the tip of Southeast Asia, and being concerned about whether we do not have some responsibility for the maintenance of the balance of power, or the balance of tensions, which, in the imperfect world in which we live, provide our only semblance of stability.... ${ }^{74}$

Brinton replied that the international system simply had too many moving parts to provide a neat answer, "especially since the freeing of the colonies and so forth and so on-and what part changes in them will play in the big balance is really awfully hard to estimate." 75 Brinton was suspicious of Dulles and the domino theory, instead agreeing with Walter Lippmann, who argued that a true balance of power would require China to have as much influence in Asia as the U.S. did in Latin America. ${ }^{76}$

In his final words, Brinton appeared to share Fulbright's exasperation with the U.S.'s Vietnam policy, though couched in a far more reticent tone. It was doubtful that American national security could be fundamentally affected by a small and "unimportant" territory, and Vietnam was not a "sufficient menace" to commit U.S. forces to mainland Asia. Ultimately, Brinton questioned "the American tradition of virtuous interference." Even in situations that were intensely problematic, such as apartheid South Africa, "officially even when we are outraged by what goes on in South Africa we should do nothing."77 Brinton's advice was that Americans "should work against our

\footnotetext{
${ }^{71}$ Ibid., 17.

${ }^{72}$ Ibid., 24.

${ }^{73}$ There was, perhaps unsurprisingly, no mention of the "excesses" of Western imperialism, slavery, or colonialism. SCFR, "Statement of Dr. Crane Brinton, Professor of History, Harvard University," 27-8.

${ }^{74}$ SCFR, "Statement of Dr. Crane Brinton, Professor of History, Harvard University," 32-3.

${ }^{75}$ Ibid., 33.

${ }^{76}$ Ibid., 32-3. This became a foundational tenet of Nixon's triangular diplomacy.

${ }^{77}$ Ibid., 36.
} 
irrational attitudes toward revolution and above all also attempt to weaken the delusion of the potency of our virtues." The United States must lose its presumption of "omnipotence" and be prepared to address crises in the global order on a case-by-case basis. This included revolutionary movements, no matter how communistic or distasteful:

Brinton: We should put up with a world that isn't our own making. We have to anyway. Fulbright: In other words, if I understand you fairly, we shouldn't be sympathetic only to revolutions that are in our own image; we should allow revolutions that may be different to ours to work themselves out. Is that correct?

Brinton: I think that would be a piece of real wisdom. ${ }^{78}$

Louis Hartz was prominent both as an academic with Harvard's "government set" and as a public intellectual. ${ }^{79}$ In 1952, Hartz had presented what became one of his signature interpretations of American politics: the American Revolution did not so much create a new nation as it consolidated one, formalizing a process of self-determination ongoing since the early $1600 \mathrm{~s}$. The Revolution had not created a free people; it was made by a free people who had already shed the trappings of monarchism and the internecine conflicts that characterized seventeenthand eighteenth-century Europe. As Hartz began, "Even in the glorious days of the eighteenth century, when America suddenly became the revolutionary symbol of Western liberalism, it had not been easy to hide the free society with which it started." 80 Americans were reluctant revolutionaries, a paradox central to American political life: "If America was from the beginning a kind of idyllic state of nature, how could it suddenly become a brilliant example of social emancipation? Two consolations were being extracted from a situation which could at best yield only one." ${ }^{\prime 1}$ Americans may have displayed exuberant pride in the revolutionary heritage, but they did not understand or approve of the cyclical outbursts of political violence in Europe:

The fact that the Americans did not have to endure a "democratic revolution" deeply conditioned their outlook on people elsewhere who did; and by helping to thwart the crusading spirit in them, it gave to the wild enthusiasms of Europe an appearance not only of analytic error but of unrequited love. Symbols of a world revolution, the Americans were not in truth world revolutionaries. ${ }^{82}$

Hartz refined this argument in The Liberal Tradition in America (1955), declaring that "American liberal culture was established by the Puritan migration of the seventeenth century, rather than by social revolution." ${ }^{\prime 3}$ With the heroic Puritan flight from medieval Europe, the new Americans (and, by extension, all Americans thereafter) escaped the need for a true social

\footnotetext{
${ }^{78}$ Ibid., 50.

${ }^{79}$ In 2005, Society reprinted Hartz's testimony. As Paul Roazen wrote in the introduction, despite the prominence of Harvard academics in Kennedy and Johnson administration circles, it was still testament to Hartz's status that Roazen "could think of no other example of a prominent political theorist being asked by Senators for his or her viewpoint; Hannah Arendt's own On Revolution had appeared in 1963, but it was a sign of Hartz's standing by 1968 that it was he who was to appear [in person]." Louis Hartz, "Profile: Louis Hartz, The Nature of Revolution," Society 42, no. 4, (May/June 2005): 54-61, here 54-6. Hartz's stellar career ended sadly, after a psychological break in 1974 necessitated his resignation from Harvard. He died in Istanbul in 1986. See also James T. Kloppenberg, "Resquiet in Pacem: The Liberal Tradition of Louis Hartz," in The American Liberal Tradition Reconsidered: The Contested Legacy of Louis Hartz, ed. Mark Hulliung (Lawrence, KS, 2010), 90-124..

${ }^{80}$ Louis Hartz, "American Political Thought and the American Revolution," The American Political Science Review 46, no. 2 (June 1952): 321-42, here 321.

${ }^{81}$ Ibid., 321-2.

${ }^{82}$ Ibid., 323.

${ }^{83}$ SCFR, "Statement of Dr. Louis Hartz, Professor of Government, Harvard University," 110.
} 
revolution. ${ }^{84}$ In this reading, the violence and tumult of 1776 was in fact "a reflex action, a shaking off by a liberal fragment of Europe of some of the medieval marginalia which clung to it as it migrated across the Atlantic." Therefore, it was "unnecessary to guillotine [the old feudal enemies] or to struggle with their ghosts after death." Hartz's interpretation, of course, remains a fascinating exercise in cultural forgetting; not only did it ignore the racial, class, and cultural conflicts of the colonies, it overlooked how the rebels thought of themselves, acutely aware that they were embarking on a radical and potentially treasonous political experiment. But it also presented a useful truth. The American colonists were British subjects who, until the Olive Branch Petition of July 5, 1775, continued to desire this status. ${ }^{85}$ In fact, Hartz argued that the closest the U.S. came to a true social revolution was the Civil War, and the most revolutionary aspect of the tumult of the 1860s was a radical rethinking of the "definition of the Negro" and of the meaning of the Declaration of Independence. However, even these potentially destabilizing events in American society were swiftly tempered by what Hartz called the "miracle of Reconstruction." 86

Hartz's "liberal thesis" formed the basis of his Senate testimony in 1968. Americans, he declared, became a fully formed, "spiritually and socially democratic" people in relative isolation. ${ }^{87}$ Protected by an ocean and insulated from Europe's travails, the vastness of the continent ensured that Americans evolved a unique fitness for self-government, with no need for a violent revolution. Neither Americans nor their observers correctly grasped the extraordinariness of this experience. Additionally, while Americans would always have an affinity for "liberal objectives," these sympathies were "always dampened in the end for the American by the inexplicable inability of the foreigner to be sufficiently moderate, sufficiently successful." 88 Americans watched other peoples' revolutions from the safety of across the Atlantic, initially championing "liberal struggles for liberal institutions, especially if it involved the issue of national independence." But when the struggles became too violent for American sensibilities, when they began to involve "hanging and shooting," such as in Latin America, "the 'mild and merciful' peoples of North America proceeded to withdraw their affection." ${ }^{89}$ Unlike Brinton, Hartz was not a specialist on revolutions, admitting only a certain level of comfort with models derived from the Western tradition. Hartz employed the French Revolution synecdochically for all violent revolutionary outbursts, whether communist-inspired or otherwise. By collapsing all revolutionary struggles into the French model, Hartz elided all differences between moments of upheaval. It was a simple equation-all other revolutions were "French Revolutions," and "French Revolutions always fail in contrast to the enormous success of American democratic developments." 90

\footnotetext{
${ }^{84}$ Ibid., 112.

${ }^{85}$ The Petition to George III, King of Great Britain, 1775, known as the "Olive Branch Petition" was a final attempt to assert the rights of the colonists while remaining loyal to the British Crown. See Manuscripts and Archives Division, The New York Public Library, "Petition to George III, King of Great Britain, 1775," New York Public Library Digital Collections, http://digitalcollections.nypl.org/items/ab95da80-8a11-0132-314e$58 \mathrm{~d} 385 \mathrm{a} 7 \mathrm{bbd} 0$.

${ }^{86}$ SCFR, “Statement of Dr. Louis Hartz, Professor of Government, Harvard University," 114-5.

${ }^{87}$ Ibid., 113-4.

${ }^{88}$ Ibid., 110 .

${ }^{89}$ Ibid., 115.

${ }^{90}$ The notion that, due to the level of violence and to the restoration of the monarchy, the French Revolution had "failed" was a common one, evident from writers as diverse as Thomas Jefferson to Irving Kristol. As Kristol wrote in 1973: "It is certainly indisputable that the world, when it contemplates the events of 1776 and after, is inclined to see the American Revolution as a French Revolution that never quite came off, whereas the Founding Fathers thought they had cause to regard the French Revolution as an American Revolution that had failed." Irving Kristol, "The American Revolution as a Successful Revolution," Oct. 12, 1973, delivered at Washington, DC, in American Enterprise Institute's Distinguished Lecture Series (Washington, DC, 1973), 3.
} 
By assuming that the American iteration of revolutionary nationalism was universal and "instantly relevant to all societies," Americans had inadvertently "masked the relativity of [their] history." 91 The romantic belief that Americans considered themselves the "true revolutionaries of the world" was erroneous. Indeed, the most remarkable thing about American development was its industrial capacity, not necessarily its political models. ${ }^{92}$ This helped to explain the U.S.'s current foreign policy predicament regarding the rash of anticolonial revolutions in the emerging nations of Africa and Asia. According to Hartz, the new nations were underdeveloped in the most literal definition of the term, emerging from a "premodern world of values." Nations such as India and Nigeria were only beginning to "accomplish the cultural break with medievalism" that the United States underwent in the 1700s. ${ }^{93}$ After the Revolution the U.S. was "in a certain economic sense an underdeveloped country which [made] our history analogous to newly independent Asian and African countries," but American industry was soon "staggeringly successful." The United States quickly developed a unique tradition of modernity and utilitarianism "even more advanced than that of Europe." 94 National liberation movements could not invoke or appropriate the revolutionary discourse, spirit, or success of 1776, because the American Revolution was best conceived of as an "escape from revolution," not an appeal to revolution.

During the question period, Fulbright inquired if a lack of experience with revolutions "of the French sense" impeded the nation's understanding of contemporary world revolutions. Hartz expressed no doubt: this lack of firsthand experiences was indeed an "interfering aspect of our understanding of revolutions elsewhere." Yet he was quick to add, "this is not to justify revolutions elsewhere. It is simply to say that to the extent that a nation is conditioned by its history, we are not conditioned to understand this peculiar kind of experience." 95 This explained the American disillusionment with revolutions in other places; no matter how promising the drive to shake off the despotism of communism or some ancien régime, these movements were bound to disappoint American observers, who were ill-suited to such radicalism and violence. As Hartz poetically noted, "from the French Revolution onward the American response to revolution abroad is like a love affair, which is constantly turning sour, which is forever ending in disenchantment." ${ }^{\text {"9 }}$

But were all revolutions equally problematic? Hartz argued that Americans were ill-equipped to deal with revolutions in principle, but communist-inspired revolutions were especially objectionable. As Hartz put it, "we did not have to assess the French Revolution in terms of world politics, for the most part we could assess it just as a revolution. But revolution today is so deeply ingrained in world politics that an additional factor has entered into the picture."97 Like Brinton, Hartz assumed that revolutionary politics were now a perpetual fixture of political life. And, like Brinton, Hartz was skeptical of what he considered the U.S.'s proclivity for intervention. The current geopolitical complexities had forced what Hartz called the American "return to the world." 98 The United States was conditioned by the flight from European feudalism and its discontents, and in time developed its unique values and institutions. The nation was now in a "tug of war" between its newer Wilsonian impulses and its original, so-called isolationist imperatives, a dilemma the Founders had the foresight to fear, though they never

\footnotetext{
${ }^{91}$ SCFR, “Statement of Dr. Louis Hartz, Professor of Government, Harvard University,” 119.

${ }^{92}$ Ibid.

${ }^{93}$ Though Hartz does not state it outright, this argument is redolent of Walt Rostow's famed theories of economic take-off in the 1960s in The Stages of Economic Growth: A Non-Communist Manifesto (Cambridge, UK, 1960).

${ }^{94}$ SCFR, “Statement of Dr. Louis Hartz, Professor of Government, Harvard University," 120.

${ }^{95}$ Ibid.

${ }^{96}$ Ibid., 115.

${ }^{97}$ Ibid., 126.

${ }^{98}$ Ibid., 129.
} 
envisioned the scope of American insertions into the world. In the postwar period the country fell victim to its own success, forced to "return to the world," as its unique global position compelled a constant reckoning with unstable and immoderate political messes elsewhere. For Hartz, this represented a "fundamental" change, because it partially "un[did] the work of the seventeenth century":

Now, when a country has had experience only with a single way of life ... and that country is thrown back into the world and has to deal with other people, the inevitable instinct of the country is to spread its way of life to others. This is not merely because its outlook seems the only legitimate one since no others have been encountered but also because it is hard to have a rational conversation with people completely outside the ken of your own experience. ${ }^{99}$

Karl Mundt (R-SD) arrived late to the hearings and missed Hartz's prepared statement. Mundt, one of the Committee's few staunch conservatives, was a McCarthy loyalist and had chaired the Subcommittee on Investigations for the Army-McCarthy Hearings. In a pointed exchange, Mundt asked, "I presume that the purpose of these Hearings is to try to determine, as a nation which was born in the crucible of revolution, what should subsequently be our attitude toward other revolutions in other areas of the world.... Do you feel that this country should seek to mold the rest of the world into its own image?" ${ }^{100}$ Hartz dodged the question with an intellectual sleight of hand, avoiding the thorny issue of the nation's revolutionary heritage by reiterating his central argument: "America did not arise out of a revolutionary experience but rather out of a migration experience." Moreover, the question itself was moot since revolutions of the American type, that is, migrations to "free" land, were no longer possible. Revolutionary escapes of the sort that created the United States "no longer exist. The experience out of which the United States was created is gone practically forever from world history," in part because "the luxury of aboriginal destruction has also disappeared from world history, not because there are no new places to go but because the humanitarian conscience of the world will not permit that." ${ }^{\prime 01}$ The United States had forever lost the "luxurious irresponsibility of the nineteenth century." 102

Americans valued the concepts of liberty and democracy, but only in forms that they considered appropriate and intelligible-what Hartz called a "problem of form and substance." ${ }^{103}$ Drawing a distinction between democracy as a political style (as demonstrated by American political institutions) and democracy as a broad social good (as demonstrated by the loud appeals to democracy emanating from communist states and the conspicuous use of the term "democratic" in much Marxist discourse), the very word was in danger of losing all meaning. When so many communist or otherwise questionable entities claimed the adjective democratic, unwittingly the United States was now viewed as a "reactionary" state. ${ }^{104}$ Similarly, though the idea of liberty had been "monopolized by polemicists," Americans had to come to terms with the idea that others might conceive of liberty in different registers, and to learn to "disentangle meanings" to converse with other cultures. ${ }^{105}$ For Hartz, U.S. foreign relations was a tragic tale, as a nation forced to "return to the world" was a nation

\footnotetext{
${ }^{99}$ Ibid., 127, 129-30.

${ }^{100}$ Ibid., 141.

${ }^{101}$ Ibid., 149.

${ }^{102}$ Ibid., 118.

${ }^{103}$ Ibid., $146-7$.

${ }^{104}$ Ibid., 125.

${ }^{105}$ Hartz, not known for his sensitivity on social issues, even acknowledged that "we may even come to an assessment of American society which sees in it the absence of quite a number of liberties which we would like to see present here." SCFR, “Statement of Dr. Louis Hartz, Professor of Government, Harvard University,” 134, 147.
} 
condemned to a constant negotiation of a disorderly globe unable to benefit from the American example.

Brinton and Hartz were but two voices in a decades-long conversation about the American intervention in Vietnam. But they were also voices in the centuries-long conversation about the meaning of the American Revolution. For Brinton, Americans tended to "sympathize with people seeking to be free generally, yes. But where revolution threatened our way of life directly, and I think it is natural, we are not sympathetic." ${ }^{106}$ Brinton concluded that peoples around the globe would continue to fight for new visions of their futures, to expound ideologies that Americans considered radical or dangerous, and to create nation-states that did not conform to American values or institutions. In short, there would continue to be revolutions out of step with the "spirit of '76," and automatic hostility to these events was not a viable foreign relations strategy, especially not for a great power in the middle of bipolar nuclear competition. For Hartz, the Puritan flight and fight against English oppression had produced an exceptional people, dedicated to liberty, self-determination, and republicanism. He concluded that the American experience simply could not be replicated, or by extension, exported.

The implications of this decided ambivalence are profound. ${ }^{107}$ Other peoples, impressed by the American example, appealed to American goodwill by invoking the radical spirit of the Founding Fathers for their own revolutions, as Ho Chi Minh did in 1945. Yet these movements would likely fail to achieve an American-style democracy or to win U.S. approval. American elites expended significant energy attempting to modernize and develop other peoples, and to channel and contain their revolutionary impulses. Many academics, activists, and policy makers sincerely believed that with the correct guidance or strategic application of political, military, or economic pressure, it should be possible that certain foreigners could become "potential Americans" and share in the proverbial blessings of liberty. ${ }^{108}$ But how often were such initiatives successful? Americans mainly found themselves opposed to sociopolitical revolutions during the twentieth century, on the side of stability rather than liberty.

Though the Nature of Revolution Hearings were not a marquee political event, they exposed deep-seated concerns over the right to revolt and the fear of political instability. They also revealed that the members of Foreign Relations Committee still felt themselves the heirs of revolution and a model to the world, despite decades of foreign policy that suggested otherwise. Ultimately, the Foreign Relations Committee was not ready to concede the U.S.'s revolutionary bona fides, even as it reluctantly accepted the idea that since the 1850s (and possibly the 1790s) American policy had generally appeared hostile to revolutions.

By examining U.S. foreign relations through the lens of historical thinking about revolution, Fulbright hoped to disentangle American policy from the reflexive militarization of containment and the increasingly expensive pattern of anticommunist interventions around the globe. If the struggle in Vietnam concerned communist agitation, then the United States should stake its credibility on preserving an island of illiberal democracy in Southeast Asia. But if it was a true nationalist revolution, then the nation's critics were correct: at worst, the most powerful nation had used its considerable might to stymie the will of the people and had entrapped itself in a morally and strategically suspect war; at best, it had remained remarkably heedless of the perils of interventionism. Turning the analytical lens inward forced a conceptual recalibration:

\footnotetext{
${ }^{106}$ SCFR, "Statement of Dr. Crane Brinton, Professor of History, Harvard University," 30.

${ }^{107}$ Indeed, during Brinton's testimony when Frank Case invoked Hartz's assertion that Americans had never really had a "class society and we never had to revolt against it," Brinton, familiar with Hartz's ideas, replied: "We never had an external enemy that we were really afraid of." SCFR, "Statement of Dr. Crane Brinton, Professor of History, Harvard University," 39.

${ }^{108}$ Thomas Borstelmann, "Inside Every Foreigner: How Americans Understand Others," Diplomatic History 40, no. 1 (2016): 1-18, here 3 .
} 
it was one thing to be at odds with the powerful and antagonistic Soviet Union, but it was something else entirely to police the globe, hostile to all potentially revolutionary situations.

The unique validity and universal relevance of the American Revolution remain the ideological substrates upon which decades of American foreign relations thinking developed-an extension of the exceptionalism that characterized the nation's foundational myths. More investigations of American conceptions of what Michael Hunt called "ordered liberty" and the American Revolutionary imaginary are needed, and how these preoccupations, especially discursively, were woven within foreign policy during the twentieth century. ${ }^{109}$ To do this successfully historians need to look carefully at a wide variety of published and unpublished sources. The American Revolution served different political uses for different actors, and the disputed and politically malleable legacy of the Revolution posed intellectual, moral, and policy challenges for American decision makers-a series of tensions made explicit in the SCFR conversation on the nature of revolution. In 2003, Randall Bennett Woods argued for the existence of four lasting themes in American foreign relations history: isolationism, unilateralism, exceptionalism, and internationalism. ${ }^{110}$ Should ambivalence toward revolution be added to this list? The United States's very exceptionalism had become a foreign relations liability, and throughout the twentieth century revolutions remained a problem entangled with its destiny.

Candace Sobers is an assistant professor of history and global and international studies at Carleton University. She is a historian of international history and modern international relations, specializing in twentieth-century decolonization and United States foreign relations. Her current book project examines the roles of post-1945 African independence movements in the making of the twentieth century international system.

\footnotetext{
${ }^{109}$ "Ordered liberty achieved by others would confirm for Americans their leading role in a secure world of free peoples, Revolutions gone astray, on the other hand, would leave Americans feeling repudiated, isolated, and anxious." Hunt, Ideology and U.S. Foreign Policy, 97.

${ }^{110}$ Randall Bennett Woods, ed., Vietnam and the American Political Tradition: The Politics of Dissent (Cambridge, MA, 2003), 1-2. Woods's is not the only taxonomy of this sort-H. W. Brands, Anders Stephanson, Michael Hunt, and others have all offered ways of classifying the U.S.'s foundational narratives.
} 